\title{
Business Taxes and the Electoral Cycle
}

\author{
Dirk Foremny* $\quad$ Nadine Riedel ${ }^{\dagger}$ \\ Monday $17^{\text {th }}$ March, 2014
}

\begin{abstract}
The purpose of this paper is to assess whether the timing of elections affects tax policy choices. To do so, we exploit information on the German local business tax which is set autonomously by German municipalities. As the dates for local council elections vary across German states, the data allows us to disentangle effects related to the timing of elections from common trends. The findings support the notion of a political cycle in tax setting as the growth in local business tax rates is significantly reduced in the election year and the year prior to the election, while it significantly increases in the year after the election. This pattern turns out to be robust against a number of sensitivity checks.
\end{abstract}

Keywords: local business tax choice, political budget cycles, political economy, election cycle

JEL Classification Numbers: H25, H71, D72

* Institut d'Economia de Barcelona (IEB), University of Barcelona, email: foremny@ub.edu

$\dagger$ University of Hohenheim, Oxford University CBT \& CESifo Munich, email: nadine.riedel@unihohenheim.de 


\section{Introduction}

The last decades have seen a strong and rising interest in identifying the determinants of corporate tax setting behavior. Recent theoretical and empirical papers stress that corporate tax rate choices are influenced by the size and structure of the economy, the government's budgetary situation and tax competition (see e.g. Bucovetscy, 1991; Wilson, 1999; Buettner, 2003; Devereux, Lockwood, and Redoano, 2008). One aspect that has been rather neglected though is the impact of political economy determinants on corporate tax rate choices. One key question in this area is whether politicians engage in opportunistic behavior and deliberately manipulate government policies over the course of the electoral cycle in order to increase their reelection prospects.

Traditional papers in this area suggest that, in a world with asymmetric information, incumbent politicians have an incentive to signal their competency by increasing public spending prior to elections in order to boost the economy (see e.g. Nordhaus, 1975). Empirical evidence for this type of spending cycles has been rather mixed though (see e.g. Alesina, Roubini, and Cohen (1997) and Drazen (2000) for an overview). A more recent strand of the theoretical literature has suggested that politicians may use adjustments of short-run policy instruments, like tax policy choices, to demonstrate their competency to the electorate rather than through spending-induced changes of the economic conditions (see e.g. Persson and Tabellini, 2001). This predicts a political business cycle in tax rates in the sense that tax increases tend to be delayed until after the election, while the probability of tax decreases is increased in the election year and the year prior to the election. While political budget cycles in key budgetary elements such as spending and deficits are frequently found in European data, empirical evidence for this type of systematic tax rate manipulation is, however, scarce at best.

The present paper contributes to this literature and tests for political cycles in tax rate adjustments. Our empirical analysis uses the German local business tax as a testing ground which is set autonomously by German municipalities. The analysis is based on a unique and rich panel data base of around 8000 German municipalities and their political, social and budgetary situation for the time period between 2000 and 2008. As election dates vary across local councils, the data allow us to disentangle effects related to the timing of elections from common trends.

Descriptively, our data suggest a strong trend to increase the local business tax rate during the covered time period. While more than half of the communities in our sample raise their local business tax rate once or more during our sample period, only a small fraction of around $5 \%$ of the communities enacted a tax decrease. This pattern largely reflects a number of expenditure shocks at the local level within our sample period driven by rising costs for the provision of social services and a number of reforms that shifted public responsibilities to 
the local level. In consequence, communities were forced to adjust their local business tax rates as the major revenue instrument at their own discretion.

The purpose of this paper is to assess the timing of these local business tax rate changes and to test whether it follows a systematic pattern induced by the electoral cycle. To do so, we estimate panel models which determine the effect of elections on the annual growth rate of local business taxes. In robustness checks, we also use logistic models to determine the impact on the probability that a municipality increases or decreases its local business tax rate. Our results provide strong evidence in favor of an electoral cycle. Specifically, we find that tax rate growth and the probability to observe an increase in the local business tax rate are significantly lower in election and pre-election years, while they jump up in the post election years. The effects are quantitatively important. Our preferred estimates suggest that, relative to other years, the growth rate of local business tax rates is, evaluated at the sample mean, reduced by more than $40 \%$ in election years and increased by around the same amount in post-election years. This result is robust to controlling for a large number of economic, social and budgetary characteristics as well as municipality fixed effects.

As indicated above, our paper relates to the empirical literature on political budget cycles. The majority of papers in this literature focuses on spending cycles and reports rather mixed evidence (see Alesina, Roubini, and Cohen, 1997). We are aware of only three earlier papers that assess political cycles in tax rates. Mikesell (1978) and Nelson (2000) analyze the effect of elections on the adjustment of US state taxes in the post-war period. While they do find patterns which are in line with the notion of political tax cycles, their identification approach is purely descriptive and does not account for any type of heterogeneity between US states. Thus, their qualitative and quantitative results may suffer from problems related to omitted variables. A recent paper by Dahlberg and Mörk (2011) provides evidence for electoral effects on tax rate changes by combining Swedish and Finish data on local governments. In their study, variation in election dates arises only between the two groups of Swedish and Finish municipalities which differ in their institutional characteristics and may be subject to heterogeneous shocks. Our estimation approach tackles these problems by exploiting variation in election timing across federal states within the same country and by controlling for both, time-constant and time-varying heterogeneity in the social, political, and budget situation of municipalities.

The remainder of the paper is structured as follows: Section 2 provides a brief theoretical motivation for our analysis, Section 3 presents our data set and gives a brief overview over the institutional background for the German local business tax. Our estimation strategy is described in Section 4. Section 5 presents the results and Section 6 concludes. 


\section{Theory and related literature}

One of the main elements of fiscal policy is politics. The main reasoning is, as Tufte (1978) summarizes, that "as goes politics, so goes economic policy and performance. This is the case because, as goes economic performance, so goes the election." This relationship has been studied extensively by the theoretical and empirical literature on political business cycles and political budget cycles. The central idea of a political business cycle is that politicians have an incentive to implement demand-increasing policy measures prior to elections in order to boost the economy which then affects key macroeconomic variables, such as unemployment, output, and inflation (Nordhaus, 1975; Lindbeck, 1976). The empirical evidence for such a political cycle in macroeconomic performance is, however, rather mixed (see Alesina, Roubini, and Cohen (1997) and Drazen (2000) for an overview). On theoretical grounds these models were criticized for their assumption of non-rational and myopic voters, which are easy to fool by such means.

Subsequent papers drop the irrationality assumption and focus on information asymmetries between voters and politicians. Rogoff and Sibert (1988) and Rogoff (1990) investigate fiscal choices in a game where politicians signal their level of competence. As a result, fiscal policies are distorted in election years. An important difference to the earlier papers is that these models predict distortions in main budgetary concepts, such as spending, revenues, deficits, and taxes rather than in macroeconomic indicators. It has been argued that politicians may want to implement expansionary politics in election and pre-election periods to signal their competency to the electorate by a higher level of public good supply at constant levels of taxation or by implementing low-tax policies for a given public good provision. Beyond these signalling considerations, incumbents may want to implement political actions in pre-election years, which in a very general sense are likely to be appreciated by the electorate and which might thus increase their reelection probability. Analogously, as voters face high costs of ousting unpopular politicians from office in non-election years and "unpopular actions in nonelection years may be heavily discounted by election time" (Nelson, 2000, p. 544 ) if voters have short memories, politicians have an incentive to implement unpopular decisions at the beginning of the election period when the time span to the next election is as large as possible.

Following most of the empirical literature, we do not aim at providing an explicit test of political budget cycle models. As noted by Kneebone and McKenzie (2001), doing so is difficult since a measure for government competency is needed. Instead, we test a reduced form of political budget cycle models by investigating whether tax rate choices are determined by election dates. There is a large and still growing literature testing for election effects in public policy. Most of this literature finds evidence in favor of political budget cycles across European and OECD countries. Alesina, Roubini, and Cohen (1997) provide 
an exhaustive overview. Recent work of Schuknecht (2000), Persson and Tabellini (2003a,b) and Shi and Svensson (2006) report results which are in line with political spending cycles at the national level. ${ }^{1}$ Hallerberg, Strauch, and von Hagen (2007) show that public debt of European Union countries tends to increase more in election years. In particular after the set-up of the European Monetary Union members of the Eurozone have systematically run fiscal expansions during election years (Buti and van den Noord, 2003; von Hagen, 2006; Mink and de Haan, 2005; Efthyvoulou, 2012). Similar evidence for an effect of elections on debt in OECD countries is found by Alt and Dreyer Lassen (2006). ${ }^{2}$

Using data collected at the country level obviously has a number of limitations, first and foremost that it commonly does not allow to perfectly control for all other institutional and monetary differences across countries. In line with Rogoff's advice to "look at data for state and local elections, instead of concentrating solely on the small number of observations available for national elections" (Rogoff, 1990, pp. 34), using a panel at the sub-national level with data for several regions or local governments which operate under similar regulations in one country can solve this problem. Empirical contributions using sub-national data commonly find election effects in budgetary components. As the first empirical contributions using sub-national data, Blais and Nadeau (1992) find that government spending of Canadian provinces does increase in election years and this extra spending translates into a high deficit, while Rosenberg (1992) finds a significant increase of spending in pre-election years for Israeli municipalities. ${ }^{3}$ However, the advantage of institutional homogeneity and more data points when using sub-national data comes at a cost: in most of the applications, local election dates do not vary across observations.

The focus of our paper is on business tax rates as one of the most directly visible elements of local public finance. Some of the earlier studies do investigate electoral effects in revenues, in particular the share of revenues generated by taxation. However, it is not clear why these revenue shares should be a signal of competence to voters. Lower revenues at a given tax rate

\footnotetext{
${ }^{1}$ Persson and Tabellini (2003a) moreover suggest that electoral cycles differ across political systems. Their evidence suggests that, while pre-election tax cuts are a universal phenomenon, post-election fiscal adjustments (spending cuts, tax hikes and rises in surplus) tend to be present in presidential democracies. Majoritarian electoral rules are associated with pre-electoral spending cuts, while proportional electoral rules are associated with expansions of welfare spending both before and after elections.

${ }^{2}$ This paper confirms a political budget cycle conditional on the degree of transparency of the budget process and qualifies the results of Brender and Drazen (2005). They claim that budget cycles are only a phenomenon of countries which recently have become a democracy. However, according to the vast majority of studies the occurrence of political budget cycles across European countries is a well established result.

${ }^{3}$ Other studies with a focus on sub-national governments provide evidence for electoral cycles in spending and deficits for the German state level (Galli and Rossi, 2002), for Sweden (Pettersson-Lidbom, 2001), for regional governments in Russia (Akhmedov and Zhuravskaya, 2004), and for Colombian municipalities (Drazen and Eslava, 2010). Veiga and Veiga (2007) and Baleiras and da Silva Costa (2004) provide evidence for political expenditure cycles for Portuguese municipalities, as does Kneebone and McKenzie (2001) for Canadian provinces. Dahlberg and Mörk (2011) show that elections impact on public employment using data for Sweden and Finland. The fact that these studies do find political budget cycles for well established democracies casts further doubt on the new-democracy hypothesis of Brender and Drazen (2005).
} 
for instance could be seen as exactly the opposite, the government's inability to administer the tax collection. A notable exception is the paper of Dahlberg and Mörk (2011) which also accounts for changes in statutory tax rates.

Apart from that, the effect of electoral cycles on tax setting behavior is rather unexplored. We are aware of only two studies which, in a descriptive way, assess the effect of elections on the tax policy choice of US states. Mikesell (1978) and Nelson (2000) investigate how electoral cycles impact on the changes in tax rates and the adoption of new taxes for US states. Both papers report evidence for a strong political cycle as tax increases occur with a higher frequency the larger the time until the next election. However, results are based on a purely descriptive approach and do not account for cross-sectional or longitudinal heterogeneity which may be correlated with the states' tax policy and confound the results.

We account for these shortcomings and use a more rigorous empirical identification strategy to test for political cycles in the context of the German local business tax. If the above theoretical incentives are relevant for political decision making, local politicians in Germany may want to signal their competency to the electorate by keeping local business taxes low, for a given amount of public good provision. Following this line of argument, we expect a reduced probability for tax increases prior to elections and a higher one once the election took place. Note in this context that, beyond the competence signal, increases in the local business tax might be unpopular with voters in a very direct sense as tax increases likely exert an effect on the inhabitants' after-tax income. The German local business tax is levied on unincorporated as well as incorporated businesses and reduces their after-tax income. Business owners are often residents and hence voters in the community and are thus directly harmed by the tax increase. They also act as an influential multiplier, since they can easily express their opinion over public policies to their costumers which are part of the electorate. In addition, several studies suggest that a significant fraction of corporate and business taxes are borne by workers (see e.g. Arulampalam, Devereux, and Maffini, 2007; Desai, Foley, and Hines, 2007), which may also make business tax increases unpopular with the electorate. Thus, especially if voters do have short memories, this may give rise to electoral cycles in the choice of the local business tax.

Following these considerations, we will assess the existence of electoral cycles in the tax rate setting behavior of German municipalities. Precisely, we will investigate whether business tax rates are significantly reduced in pre-election and election years, and significantly increased in post-election years. In doing so, we use panel estimators and exploit that local election dates in Germany vary across federal states. This allows us to separate common shocks to all municipalities from potential effects related to the electoral cycle.

Note that our empirical analysis does not allow us to distinguish between the above described theories where elections act as a device to select the most competent policymaker (see Rogoff (1990) and also Banks and Sundaram (1998), Besley (2006)) and alternative 
mechansisms that predict electoral cycles in settings where elections curb moral hazard behavior (see e.g. Ferejohn (1986)). While the models' exact empirical predictions depend on various assumptions, such as the policy process, the motivation of incumbents, and the information set of voters, they, in a general interpretation, share a common prediction on the pattern of the tax cycle (while they differ in their prediction on government spending, see Pettersson-Lidbom (2003) and Persson and Tabellini (2003a)). Since we focus on the revenue side of the budget, our analysis thus does not allow to differentiate between the mechanisms. This is clearly an interesting road for future research which goes beyond the aim of our paper though (see e.g. Ferraz and Finan (2011), Gagliarducci and Nannicini (2012), Pettersson-Lidbom (2003) for first empirical steps in this direction). ${ }^{4}$

\section{Data}

\subsection{Institutional background}

The testing ground for our empirical analysis is the local government sector in Germany. In general, the German federal system consists of three governmental tiers: the federal, state, and local governments. There are sixteen states and around 12,000 municipalities in Germany. The power to levy an individual tax rate on business income is restricted to the federal and the local government level.

The responsibilities of local governments vary only slightly across German states. Their main mandatory tasks include the construction and maintenance of roads, sewerage, kindergartens and primary schools. Other responsibilities, such as the maintenance of cultural or sport facilities, tourism, and public transport are optional. In addition, local governments are responsible to provide certain social benefits to the unemployed and the poor. Our sample period is characterized by rising expenditures at the local level due to increasing social costs and a number of federal reforms which shifted additional spending burdens on to the local government level. Examples are the law for the provision of additional kindergarten capacities by the local level ('Gesetz zum Ausbau der Kindergartenbetreuung') and additional social security payments for the elderly and the unemployed (see e.g. Deutsche Bundesbank, 2000, 2007).

While a major fraction of the funds for the provision of these services comes from state grants and redistributed tax revenues, local communities have discretion over two tax instruments at their disposal: the local business tax (Gewerbesteuer) and a local property tax (Grundsteuer). In revenue terms, the local business tax is by far the more important revenue source for local jurisdictions and significantly contributes to local government revenues.

\footnotetext{
${ }^{4}$ Further interesting extensions include the explicit assessment of voter responses to changes in local business rates and the analysis of responses of budgetary elements (revenues, spending and deficits) to election dates.
} 
The average tax rate set by German municipalities is $16.25 \%$ and makes up a considerable fraction of the tax burden on firms in Germany. ${ }^{5}$ The tax base is defined as firm profit earned within the boundaries of a municipality, town, or city. The tax applies to both - the incorporated and non-incorporated sector. The tax base definition follows the corporate and income tax law. While the tax base law is set at the national level and thus applies to all municipalities in Germany, the local council of each municipality can decide autonomously upon a so-called tax collection rate. The rate chosen is valid for at least the next entire budget year. At the local level, a budget year corresponds to the calendar year. Municipalities can change their tax rates from year to year, but not during the year. There is no upper bound for the tax rate, but a lower bound was introduced in $2004 .{ }^{6}$ The majority of the local business tax revenues remains directly with the municipalities. A small share has to be transferred to the central and regional level though, as an element of the German federal equalization scheme.

On the policy side, the election and legislative processes of local councils must be in line with the municipal codes of their hosting states. Our empirical analysis exploits the fact that the election dates of local councils differ across federal states. The election years for the eight states included in our analysis are listed in Table 1. Apart from this difference, municipal codes are similar across states. In particular, in all federal states a simple majority of votes in the local council is required to enact a change in the local business tax rate. Moreover, in all states, a large number of parties tend to take part in local elections, including the major parties which also operate at the regional or national level as well as numerous local parties and candidates. ${ }^{7}$

[Table 1 about here]

The homogeneity of the political and administrative legislation is a big advantage of our data set. In the German sub-national context, municipal codes and law differ only slightly across federal states (see also our discussion in Section 5). This offers convenient features to test our hypothesis, in particular the fact that all communities have exactly the same fiscal policy tools at hand.

\footnotetext{
${ }^{5}$ The current corporate tax rate at the national level is $15 \%$.

${ }^{6}$ The idea was to prohibit very low tax rates chosen by a small number of "tax haven" communities before 2004 .

${ }^{7}$ Note in this context that one important difference between elections at the local level compared to state or federal elections is that commonly a larger number of small parties is represented in the local council as with the former no minimum threshold of votes has to be passed in order to be considered for the allocation of seats.
} 


\subsection{Data set}

Our data set covers German communities in the period between 2000 and 2008. ${ }^{8}$ The data accounts for all municipalities in West German states (except the city states of Bremen and Hamburg ${ }^{9}$ ). We disregard communities in Eastern Germany which joined the Federal Republic of Germany in the reunification of 1990 as a major fraction of those communities was subject to mergers and local government reforms after the German reunification. Furthermore, we exclude West German municipalities which were subject to a merger and those belonging to a municipal union in Lower Saxony. Eventually, we end up with a sample of 7738 municipalities. ${ }^{10}$ Figure 1 shows a graphical representation of our sample.

[Figure 1 about here]

As mentioned above, we observe a rising trend in local business tax rates during our sample period. A majority of communities raised their local business tax rate at least once over the 9-year-period covered by our data. Only a small number of municipalities observes two or more increases, see Figure 2 for details. In contrast to the large number of tax hikes, declines of local business tax rates are rare. Only around $5 \%$ of the municipalities in our data lowered their tax rates at least once within our sample period.

[Figure 2 about here]

This pattern may on the one hand reflect increased funding needs of local municipalities as rising social costs and reforms which shifted additional obligations to the local level put pressure on community finances. On the other hand, our sample period is also characterized by two major declines in the federal corporate tax rate (in 2001 and 2008) which might in a vertical tax competition framework - increase the communities' incentive to raise their local business tax rate. Figure 4 depicts the geographical distribution of tax rate changes, showing that tax hikes and cuts are not exclusive to particular federal states. ${ }^{11}$

[Figure 4 about here]

Moreover, we augment our data set by detailed information on socio-economic and political characteristics of the communities in our data. Descriptive statistics are presented in Table

\footnotetext{
${ }^{8}$ Some data, like electoral results, are also collected for years prior to our sample period in order to determine whether our first sample year (the year 2000) is a post-election year and to determine the composition of the local council in the first sample years. The main reason for restricting the analysis to the years 2000 to 2008 is that during this period the local business tax code which is common to all German municpalities remained unchanged, while it was adjusted before and after that period. Moreover, some of the community information used in this analysis is not available in concise format for earlier years.

${ }^{9}$ We exclude the city states, because local and regional budgets are not easy to separate in this context.

${ }^{10}$ Public finance data is not available for some years in the federal state of Schleswig-Holstein.

${ }^{11}$ Note, however, that the increasing trend in German local business tax rates is not unique to our sample period. In the contrary, an increasing trend in the average local business tax rate has been observed since the late 1970ies and early 1980ies already, see e.g. Buettner (1999).
} 
2. First, we include the total number of inhabitants to capture differences in community size. The variable points to a strong heterogeneity between the municipalities in our data which includes small jurisdictions with less than 10 inhabitants as well as the city of Munich with 1.3 million people. Second, we include a number of socio-economic variables, precisely the share of young inhabitants below the age of 15 and the share of old inhabitants above the age of 65 as the demographic structure may affect local business tax choices. Third, to capture employment effects, we include the local unemployment rate, defined as the number of unemployed as a share of total population. ${ }^{12}$

[Table 2 about here]

Furthermore, we add three indicators for the municipalities' fiscal performance and economic capacity to our data set. First, we include public borrowing in each year, defined as the share of revenues that is generated by new credits, less amortization of debts. Second, we include the total outstanding debt in per capita terms. This value is obtained at the county level, but it also includes municipality-specific information on debt of hospitals and other city owned companies like transportation or sewage. Third, to control for the prosperity of a community in terms of per capita income and wealth, we also include a variable for the average private per capita income level. Last, we control for mandatory provision of services by including expenditures. All described variables show a considerable cross-sectional and longitudinal variation as indicated by large standard deviations.

Finally, we include detailed information on the seat shares of the political parties in the municipal council. We directly observe the share of the four main parties, which also run for national or regional elections. These are the center-right conservative party $\left(\mathrm{CDU} / \mathrm{CSU}^{13}\right)$, the center-left social democrats (SPD), the liberal party (FDP), and the Green party (Gruene). We create an aggregated value for all remaining political parties which mainly are locally operating civil parties. ${ }^{14}$

\footnotetext{
${ }^{12}$ Due to confidentiality reasons, this variable is censored if less than three people are unemployed. In this case the variable is set equal to zero.

${ }^{13}$ In the state of Bavaria the conservatives are not represented by the Christian Democratic Union (CDU) but by their sister party, the Christian Social Union (CSU). The CDU and the CSU do not compete against each other; they form one faction in the federal parliament.

${ }^{14}$ We also reran our estimation models additionally including indicator variables for parties at the far-left of the political spectrum (comprising Die Linke, the former PDS, and the former WASG) and for parties at the far-right of the political spectrum (comprising the nationally organized extreme right parties NPD, DVU, Die Republikaner, and some right wing parties which are only regionally active) which leaves our results unaffected, see an earlier working paper version (Foremny and Riedel (2012)). As the seat shares of these parties are negligible and, in general, information on the seat share of smaller parties is not reported by the state statistical offices for all elections in all German states in concise format, we subsume all smaller parties into one category for our baseline specifications.
} 


\section{Identification}

Our baseline analysis focuses on tax rate changes in the form of the annual percentage change of the tax rate:

$$
\tau_{i, t}^{\text {growth }}=\frac{\operatorname{tax}_{i, t}-\operatorname{tax}_{i, t-1}}{\operatorname{tax}_{i, t-1}}
$$

Alternative specifications use binary dependent variables $\bar{\tau}^{\text {binary }}$ and $\underline{\tau}^{\text {binary }}$ to assess the determinants of the general probability that a community increases and decreases its tax rate. The variable $\bar{\tau}$ is coded one if the statutory tax rate increased from the previous to the current year, and zero otherwise. Formally,

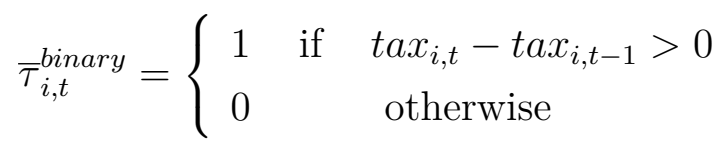

$\underline{\tau}^{\text {binary }}$ is defined analogously for tax decreases. The generic model estimated for the various definitions of $\tau$ is specified as

$$
\tau_{i, t, s}=\mathbf{t}_{\mathbf{t}, \mathbf{s}}^{\prime} \boldsymbol{\delta}+\mathbf{x}_{\mathbf{i}, \mathbf{t}}^{\prime} \boldsymbol{\beta}+\varepsilon_{t}+\mu_{i, s}+\epsilon_{i, t}
$$

where the vector $\mathbf{t}$ is a set of time period specific dummies, which we relate to election dates to test for an electoral cycle. In our main analysis, we include dummy variables for the year before an election is held, the election year, and the year after the election.

$$
\mathbf{t}^{\prime}=\left[\begin{array}{c}
t_{t-1} \\
t_{t} \\
t_{t+1}
\end{array}\right] \text { and }\left\{\begin{array}{l}
=1 \text { in the pre-election year, } 0 \text { otherwise } \\
=1 \text { in the election year, } 0 \text { otherwise } \\
=1 \text { in the post-election year, } 0 \text { otherwise }
\end{array}\right.
$$

These variables vary across federal states $s$. Individual municipalities $i$ within the borders of one state share common election dates, but variation arisis across the German states.

In addition, the estimations include a full set of year fixed effects $\varepsilon$ to capture common shocks over time affecting all our sample communities. As election dates vary across communities in different states, election effects captured by the vector $\mathbf{t}$ and the time fixed effects are both identified. Thus, the approach resembles a 'difference-in-differences' framework in which communities with no election in a particular year act as a control group to identify the effect of elections on the tax setting behavior in the treatment group of communities with an election (and on those communities in a pre- and post-election year respectively). ${ }^{15}$

\footnotetext{
${ }^{15}$ Note that our analysis exploits information on a large number of elections (20 elections in total, two to three per state).
} 
We include community fixed effects $\mu_{i}$ in the baseline model which absorb time-constant heterogeneity between jurisdictions and nest a full set of state fixed effects thus accounting for potential effects related to institutional differences between states. In terms of control variables, $\mathbf{x}$ is a vector of other potential socio-economic and political determinants that are related to the decision whether or not to change the tax rate and which vary across municipalities $i$ and over time $t$ (see the previous section for details on the variable definition).

The baseline model is estimated with usual panel data estimators. To estimate the models where our dependent variable comes in a binary form, we use a logit transformation and report the average marginal effects. Due to the nature of our data, serial correlation of errors is not a major problem. We present standard errors which are adjusted for clustering at the state-year level to capture potential correlation of residuals at these units. Note that clustering at the state level is infeasible since the number of groups is small. Nevertheless, Bertrand, Duflo, and Mullainathan (2004) show that standard errors might be underestimated in the presence of serial correlation when clustering is conducted at the state-year rather than state level. Therefore, we, in robustness checks, also make use of two-way clustering at the state-year and individual level (Cameron, Gelbach, and Miller, 2011).

\section{Results}

\subsection{Baseline model}

Table 3 presents the result of the estimation model outlined in equation (1). We regress the annual growth rate of the local business tax on the set of dummy variables for the pre-election, election and post-election year as well as a full set of community fixed effects and time-varying community characteristics. ${ }^{16}$ Model (a) assumes independence of the errors across observations. In models (b) and (c) standard errors are adjusted to allow for clustering at the community level (model (b)) and state-year level (model (c)) respectively. Model (d) accounts for two-way clustering of the errors at the state-year level and community level as described above. Additional to coefficient estimates and standard errors, the table reports the p-values and $95 \%$ confidence intervals for the coefficient estimates.

\section{[Table 3 about here]}

The specifications confirm the hypothesis of an electoral cycle in tax setting behavior. Specifically, the coefficient estimates for the dummy variables $t_{t-1}$ and $t_{t}$ have a negative sign, while the coefficient estimate for the post-election year is positive. In specifications (a) and (b) all three coefficient estimates turn out statistically significant, indicating that the growth rate in the business tax is reduced by 0.07 in the year prior to the election and by 0.17 in

\footnotetext{
${ }^{16}$ The table depicts the coefficient estimates for the electoral dummies only. The coefficient estimates for the control variables are reported in Table 10 in the appendix.
} 
the election year. Evaluated at the sample mean $(=0.37$, cf. Table 2$)$, this corresponds to a drop in the growth rate by $19 \%$ and $46 \%$ respectively. In the post election year, the estimation suggests that the growth rate is significantly increased by 0.20 , or evaluated at the sample mean, by $54 \%$. Models (c) and (d) equally derive a significant election year and post election year effect, while the coefficient estimate for the pre-election year loses its statistical significance. Taken together, this pattern is consistent with the theoretical considerations in Section 2 and suggests that politicians indeed tend to keep local business taxes low by avoiding changes prior to elections and implement tax increases in post-election years when the time gap to the next election is maximized. ${ }^{17}$

[Table 4 about here]

As described in Section 3.1, our sample period was characterized by a strong upward trend in local business taxes. While every second community increased its local business tax rate at least once during our sample period, only a minor fraction of communities opted for a tax rate reduction. To assess whether the impact of election dates on tax rate increases differs from its impact on tax rate decreases, we transform our dependent variable to capture positive growth rates $\left(\bar{\tau}^{\text {growth }}\right)$ and negative growth rates $\left(\underline{\tau}^{\text {growth }}\right)$ separately. Thus, in the construction of $\bar{\tau}^{\text {growth }}\left(\underline{\tau}^{\text {growth }}\right)$, community-year observations with negative (positive) tax rate growth are treated as zero. Specifications (a) to (b) of Table 4 reestimate our baseline model accounting for the modified dependent variables. Standard errors are adjusted to allow for clustering at the state-year level and the specifications include a full set of community fixed effects. We find the baseline results confirmed in specification (a) that investigates the impact of the electoral cycle on positive growth rates in the local business tax measure. Thus, increases in local business tax rates tend to be significantly reduced in the election year and significantly increased in the post election year. Repeating the same exercise for the negative business tax growth $\underline{\tau}^{\text {growth }}$ yields statistically insignificant coefficient estimates for all three election dummies. As the number of business tax reductions observed in our data is tiny (less than $1 \%$ of the community-year observations), this likely reflects imprecisions in the estimated effects due to limited variation in the data.

The fact that many communities do not observe a tax rate change within our sample period further suggests that a binary regression model may fit the data better. Thus, we additionally run estimation models that test for a potential impact of the election cycle on

\footnotetext{
${ }^{17}$ Replacing the full set of community fixed effects by a full set of state fixed effects yields comparable results, see a previous working paper version Foremny and Riedel (2012). The coefficient estimates for the control variables are reported in Table 10 in the appendix. Interestingly, the coefficient estimate for the community's newly issued debt relative to revenues ('credits') is positive and statistically significant in all specifications, indicating that those communities with high financing needs, as proxied by new debt issues, tend to observe higher tax rate growth than other jurisdictions. The coefficient estimates for all other control variables turn out insignificant. However, if we include state fixed effects only (see Foremny and Riedel (2012) for results), we find a strong positive relationship between population size and tax growth rates which can be also found if we consider tax hikes only (c.f. model a) of Table 4).
} 
the community's probability to increase or lower the local business tax rate. Specifications (c) and (d) of Table 4 presents the results for the marginal effects of a logit model including state level and year fixed effects. ${ }^{18}$ Model (c) assesses the effect of the election cycle on a community's probability to increase its tax rate while model (d) assesses the effect on the probability for a tax decrease. In line with the previous results, our findings are confirmed in the specification for tax hikes while the coefficient estimates for all election dummies turn out insignificant in most instances for the tax cuts. Again, we consider the latter finding to reflect the too low number of community-year observations with a tax decrease. The findings of model (c) also quantitatively correspond to our baseline estimates. Calculating marginal effects suggests that the probability to observe a tax increase is reduced by 3.0 percentage points in the election year and jumps up by 4.6 percentage points in the post election year. Relative to the unconditional probability for a tax increase/decrease, this corresponds to a change by $37 \%$ and $47 \%$.

\subsection{Robustness checks}

In a first robustness check, we assess whether the election cycle is related to changes in the composition of the local council. In general, German local politics are characterized by a relatively large number of parties as membership in the local council is not tied to obtaining at least $5 \%$ of the votes like it is the case in national and regional elections. Thus, besides the nationally and regionally operating parties, a number of civil parties are active at the local level which are mainly concerned with local policy issues and are thus difficult to classify in the left-right-spectrum. To nevertheless assess whether changes in the distribution of seats across parties impacts on the political business cycle determined in this paper, we construct a measure for changes in the ideological composition of the local council in terms of shifts in the majority for the dominant right-wing and left-wing parties. The right-wing bloc is thereby defined to comprise the center-right conservative party (CDU/CSU) and the liberal party (FDP), the left-wing bloc is defined to comprise the center-left social democrats (SPD) and the Green party (Gruene). ${ }^{19}$ From this information, we define a dummy variable indicating ideological changes in the composition of the council. The variable takes on the value 1 if an election destroys or brings about a majority for one of the blocs. Since smaller civil parties tend to receive a significant fraction of vote shares at the local level, direct changes from a left-wing to a right-wing majority or vice versa are rather rare events though.

\footnotetext{
${ }^{18}$ The coefficient estimates are presented in Table 11 in the appendix. We also estimated conditional logit models which account for unobserved heterogeneity across jurisdictions but suffer from the shortcoming that there are no convenient possibilities to compute marginal effects. The qualitative results of the conditional logit model are in line with those of the logit model including only state dummies though.

${ }^{19}$ Note that the classification in left- and right-wing parties is in line with previous papers for Germany (see e.g. Fuess and Bechtel (2008), Potrafke (2011), Furdas and Kis-Katos (2010)).
} 
Moreover, many observers believe that party ideology has not played a substantial role in German public policy over the recent decades. While the empirical evidence is more mixed (see e.g, De Haan and Zelhorst (1993), Berger and Woitek (1997), Seitz (2000), Berger and Holler (2007), Schneider (2010), Potrafke (2011), Rodden (2001) $)^{20}$, it might thus be desirable to create a measure for the change in the general composition of local council members (irrespective of party ideology) as new members may bring in new ideas and may thus increase the propensity for tax policy changes. Since our data does not allow us to identify individual members of the local council, we construct an index for the change in the seat share of different parties. Under the assumption that delegates do not switch between parties, the index is expected to proxy for changes in the composition of council members. Formally, the index for community $i$ in year $t$ reads: $I_{i, t}=1 / 2 \cdot \sum_{p}\left|s_{i, p, t, e}-s_{i, p, t, e-1}\right|$, where $s_{i, p, t, e}$ and $s_{i, p, t, e-1}$ indicate the seat shares of party $p$ in the local council of community $i$ at time $t$ in election $e$ and $e-1$ respectively and larger index values correspond to more pronounced changes in council composition $\left(0 \leq I_{i, t} \leq 1\right)$. The index construction accounts for the seat share of the four major parties (CDU/CSU, SPD, FDP and Green Party) and the aggregate of all other parties. ${ }^{21}$

[Table 5 about here]

Table 5 reports the results of specifications which reestimate our baseline model augmenting the set of regressors by interaction terms between the election cycle dummies and the variables indicating changes in the composition of the local council. As a change in council composition may first and foremost affect policy choices in the post-election year, specifications (a) and (b) reestimate specification (c) of Table 3 including an interaction between the post-election dummy $t_{t+1}$ and measures for changes in council composition. In specification (a) council change is defined as a change in the ideological composition of the local council (indicating whether left-wing or right-wing majorities are destroyed or created), in specification (b) council change is measured by changes in the general composition of the local council as defined by index $I_{i, t}$. Both specifications confirm our baseline findings in the sense that the local business tax growth rate is dampened in the election year and increased in the post election year. The coefficient estimate for the interaction term turns out positive in both specifications albeit not statistically significant. Changes in the composition of the local council thus do not appear to exert an effect on business tax rate choices induced by election dates. Specifications (c) and (d) reestimate the two specifications additionally accounting for anticipation effects by also interacting the council change dummies with the indicator variables for the election year and pre-election year respectively. All interaction terms turn out statistically insignificant in both specifications, while the baseline electoral cycle prevails.

\footnotetext{
${ }^{20}$ Existing empirical evidence is largely restricted to the federal and state level.

${ }^{21}$ Note that accounting for the seat share of smaller parties separately yields similar results.
} 
[Table 6 about here]

Furthermore, we assess the robustness of our results to including a control variable for the lagged level of the local business tax rate. The results are presented in Table 6. Specification (a) reestimates our baseline model using the growth rate in the business tax as dependent variable. The coefficient estimate for the lagged level of the business tax rate turns out negative and statistically significant indicating mean reversal in the communties' business tax setting behavior. Moreover, again, the coefficient estimates for the election year and post election year dummy turn out negative and positive respectively, whereas only the former is statistically significant at conventional significance levels though. Specifications (b) and (c) augment the binary models by the lagged level of the dependent variable. Specification (b) presents the results for the election cycle on a community's probability to increase its tax rate. In line with intuition, the coefficient estimate for the lagged dependent variable turns out negative suggesting that communities with a high local business tax are less likely to observe a tax increase. The specification also confirms our baseline findings qualitatively and quantitatively whereas both, the coefficient estimates for the election and post-election dummies now turn out statistically significant. The average marginal effect in the election year (post-election year) is -3.0 (4.6) percentage points and thus comparable to the previous findings. Specification (c) reports analogous results for the binary model indicating tax rate decreases. Here, in line with intuition, the lagged dependent variable turns out positive and statistically significant, indicating that communities with a high local business tax have a higher probability to observe tax decreases. Apart from that the results resemble our baseline findings.

\section{[Table 7 about here]}

In our baseline model, the growth rate of the dependent variable is calculated based on the community's statutory local business tax rate. A particular feature of the German local business tax, however, is that a firm's local business tax payment is itself deductible from its tax base ('self-deductibility'), implying that the firm's effective tax burden falls short from the statutory one. ${ }^{22}$ As a robustness check, we thus reestimate our baseline model using the growth rate in the effective local business tax as dependent variable. The results are presented in specification (a) of Table 7 and qualitatively and quantitatively resemble our baseline findings. As an additional modification, specification (b) reruns the baseline estimation using the change in the local business tax rate as the dependent variable instead of the growth rate. Again, the findings are comparable to our baseline estimates.

[Table 8 about here]

\footnotetext{
${ }^{22}$ Self-deductibility of the local business tax implies that the corporate tax payment $T$ is calculated as $T=t(\pi-T)$, with $t$ denoting the local business tax rate (in percentage values) and $\pi$ denoting the company profits. Rearranging yields $T=t /(1+t) \pi$. Hence, the statutory local business tax rate which is, for example, implied by a local business tax of $16.25 \%$ is $0.1625 / 1.1625=14 \%$.
} 
Our baseline model includes three dummy variables to capture the electoral cycle: a dummy variable for the pre-election year, a dummy variable for the election year and a dummy variable for the post-election year. As elections for local councils take place every five years (every 6 years in Bavaria), the two remaining years act as baseline category. In Table 8 we reestimate our baseline model using the local business tax growth rate as the dependent variable and including indicator variables for the election year, for the first year after the election, for the second year after the election, for the first year prior to the election and for the second year prior to the election separately. The pattern is very consistent with our theoretical considerations in the sense that we find a small and insignificant coefficient estimate in specification (a) which includes a dummy variable for two years prior to the election. In specification (b) we include a dummy variable for the pre-election year and find a negative effect which is quantitatively relevant, although still not statistically significant. In specification (c), which includes a dummy variable for the election year, the effect is negative and larger in absolute terms than in the previous specification and now also gains statistical significance. Including only a dummy variable for the first year after the election yields a positive and statistically significant coefficient estimate, confirming our baseline estimations (see specification (d)). Rerunning the specification with a dummy variable indicating the second post-election year again yields a positive coefficient estimate which, in line with expectation, is smaller though and does not gain statistical significance.

\section{[Table 9 about here]}

Furthermore note that our data suggests that local business tax rate choices tend to be correlated at the state level (see Figure 4). ${ }^{23}$ This heterogeneity may stem from differences in (the evolution of) the political, economic or social situation across states which might induce differences in revenue needs at the local level and hence may imply a correlation in the propensity of communities within the same state to increase or decrease their local business tax rate. As an example, localities in Germany are partly financed through state-level grants. Since state governments have some discretion on the generosity of these grants, state-level financing may have become systematically less generous in some states, putting an upward pressure on local business tax choices for all communities within that state relative to other states. The general propensity for communities within one state to increase or decrease their local business tax rate relative to communities in other states is absorbed in our empirical estimation models through the inclusion of a full set of community fixed effects which nest state fixed effects.

We are thus confident that the cyclical pattern in local business tax rate choices identified in our paper is not confounded by differences in the general propensity of communities in

\footnotetext{
${ }^{23}$ Precisely, Figure 4 indicates that state boundaries matter for the average local business tax choice. At the border between Baden-Wurttemberg and Bavaria, municipalities on the Bavarian side for example appear to be much less likely to raise their local business tax within our sample period than communities on the side of Baden-Wurttemberg.
} 
some states to increase/decrease their local business tax rates relative to others. Such a pattern could arise only if unobserved changes in the political, economic or social conditions hit states in systematic ways in the sense that tax-increasing state-level shocks systematically occur in post-election years while tax-decreasing state-level shocks systematically occur in pre-election years. This appears unlikely to us, especially given that our pre-, post- and election year dummies reflect information on 20 elections within our sample period (two to three per state). One may still have concerns though that our results are confounded by a small number of exceptional state level shocks. One of our sample states may for example, by coincidence, have been hit by a shock in a post-election year which may have induced its communities to simultaneously raise their local business tax rate. Analogously, another sample state might, by coincidence, have been hit by a reverse shock in a pre-election year which may have induced its communities to simultaneously lower their local business tax rate. To assess this possibility, we implement a jackknife analysis for our baseline model (specification (c) of Table 3). The results are reported in Table 9, where specification (a) excludes communities in the state of Schleswig-Holstein, specification (b) excludes communities in the state of Lower Saxony, specification (c) excludes communities in the state of Northrhine-Westphalia, specification (d) excludes communities in the state of Hesse, specification (e) excludes communities in the state of Rhineland-Palatinate, specification (f) excludes communities in the state of Baden-Wuerttemberg, specification (g) excludes communities in the state of Bavaria and specification (h) excludes communities in the state of Saarland. The general pattern of our results prevails in all specifications which supports the interpretation of our findings as evidence for electoral cycles in local business tax choices.

Note that the extent and strength of positive and negative external shocks on the local business tax choice of communities in our sample states may impact on our quantitative findings though. Precisely, a political business cycle in local business tax choices may show up through 'active' or 'passive' tax-setting responses to election dates. 'Active' responses to election dates imply that policy makers reduce local business tax choices in pre-election years and increase local business tax choices in post-election years. 'Passive' responses would in turn imply a reaction to an external shock on the local business tax rate. A community which in response to an external shock may want to lower or increase its local business tax rate may manipulate the timing of the business tax change according to election dates. While 'active' response patterns are expected to show up irrespective of the presence of external shocks to the local business tax rate, 'passive' responses are expected to show up more clearly the larger the external shocks faced by the localities. In the presence of 'passive' response behavior and heterogeneity in the local business tax shocks across states, excluding different (combinations of) states from our sample, may impact on the quantitative results. In line with these considerations, there is some variation in the quantitative strength of the local business tax cycle in the jackknife analysis. Most importantly, the qualitative pattern 
prevails in all specifications though. ${ }^{24}$

Furthermore note that our analysis has so far focussed on tax setting responses to dates for local council elections as it is the local council which eventually decides on local business tax changes in all our sample communities. As described above, the institutional context is in general highly similar across German states. ${ }^{25}$ Most of our sample states followed the same constitutional form during our sample period ('Süddeutsche Ratsverfassung'). The only exception is the state of Hesse which is still operating under a different type of the local code ('unechte Magistratsverfassung'). ${ }^{26}$ The difference in the constitutional forms concern the position of the mayor and the relationship between the mayor and the local council. But in all states the local business tax for the upcoming fiscal year is determined in the budget-bye law for the upcoming fiscal year which has to be deliberated and adopted by a majority vote of the local council. We thus do not presume institutional differences to affect the predictions for the political business cycle in tax setting behavior. As shown in specification (d) of Table 9, excluding communities in the state of Hesse from our sample moreover does not affect our results.

We cannot fully exclude though that the political business cycle identified in our paper partly reflects responses to mayoral rather than local council elections as the mayor has some role in preparing and drafting the budget-bye law. As described above, eventually it is the local council though which decides on the budget-bye law and hence on changes in the local business tax. We nevertheless collected information on election dates for mayoral elections in our sample states (apart from Schleswig-Holstein and some municipalities in Baden-Wuerttemberg ${ }^{27}$ and Lower Saxony where the according information is not provided by the state statistical offices). While election years for mayoral elections and elections of the local council are not perfectly aligned (mayoral election dates vary across communities), they are highly correlated in our data. The correlation coefficient is a large 0.61 and may make a separate identification of potential political business cycles related to council and mayoral elections difficult due to multicollinearity. We nevertheless re-estimated our baseline model augmented by three additional dummies capturing the electoral cycle for mayoral elections. While the mayoral cycle never gains statistical significance, the results for the council cycle

\footnotetext{
${ }^{24}$ Furthermore note that the fact that we do not find a political business cycle for tax reductions may point to the importance of 'passive' responses in our data relative to 'active' responses.

${ }^{25}$ We collected and compared the respective parts of the municipal codes from all federal states included in our sample. The (translated) paragraphs of the law are available from the authors' webpage.

${ }^{26}$ Note that after World War II, constitutional forms differed substantially across German states reflecting the influence of the different occupying countries ('Rheinische Bürgermeisterverfassung' in RhinelandPalatine and Saarland, 'Magistratsverfassung' in Hesse and Schleswig-Holstein, 'Norddeutsche Ratsverfassung' in North Rhine-Westphalia and Lower Saxony and 'Süddeutsche Ratsverfassung' in Bavaria and Baden-Wurttemberg). The constitutional forms were aligned in later decades. Since the 1990ies, and thus also during our sample period, the 'Süddeutsche Ratsverfassung' has been the dominant constitutional form for communities in Germany.

${ }^{27}$ We are grateful to Mustafa Yeter and Marc-Daniel Moessinger from the ZEW for sharing data on the election dates of mayors in this state.
} 
remain largely unchanged. Precisely, the post election coefficient $\left(t_{t+1}\right)$ is significant and .22 of magnitude (s.e. .1) while the election year coefficient $\left(t_{t}\right)$ is determined with -.12 (s.e. .08) and just fails to gain statistical significance at the $10 \%$-significance level. ${ }^{28}$ We thus presume our results to largely reflect responses in tax setting behavior to council elections. In any case, the interpretation of our results does not change irrespective of whether the cycle identified in the paper is driven by council or mayoral elections, as both cases imply that policy makers' decisions on local business tax rates are affected by the timing of elections.

To conclude, the results in this section are in line with an election cycle in tax rate setting. In particular, we find that tax rate growth is significantly reduced in the election year and significantly increased in the first post-election year.

\section{Conclusion}

The aim of this paper was to assess whether there is an electoral cycle in the tax setting behavior of local communities. For that purpose, we exploited rich panel information on a large set of communities in Germany. As the election dates for local councils in Germany vary across states, our data allows us to disentangle effects related to electoral cycles from common trends. Using conventional fixed effects panel methods and logit estimations, and controlling for time-constant and time-varying heterogeneity between the communities, our results provide strong evidence that tax setting is affected by election dates. Specifically, our findings suggest that the tax rate growth is significantly reduced in election years, while it jumps up in the post-election years. The effects turn out quantitatively important and suggest that, evaluated at the sample mean, tax rate growth is decreased and increased by more than $40 \%$ in the pre- and post-election year respectively. Thus, our findings suggest that political economy determinants, in particular the timing of elections, affect the tax policies of local communities. This underpins the validity of recent theoretical claims which suggest the importance of an electoral cycle in the choice of policy instruments. In the policy arena, the findings may have implications for the design of political systems and the timing, synchronization and length of political election terms.

\section{References}

Akhmedov, Akhmed and Ekaterina Zhuravskaya. 2004. "Opportunistic Political Cycles: Test in A Young Democracy Setting." The Quarterly Journal of Economics 119 (4):13011338 .

\footnotetext{
${ }^{28}$ Complete results are available on the authors' webpage.
} 
Alesina, Alberto, Nouriel Roubini, and Gerald D. Cohen. 1997. Political Cycles and the Macroeconomy. The MIT Press.

Alt, James E. and David Dreyer Lassen. 2006. "Transparency, Political Polarization, and Political Budget Cycles in OECD Countries." American Journal of Political Science $50(3): 530-550$.

Arulampalam, Wiji, Michael B. Devereux, and Giorgia Maffini. 2007. "The Direct Incidence of Corporate Income Tax on Wages." Working Paper Series 7, Oxford University Centre for Business Taxation.

Baleiras, Rui Nuno and Jose da Silva Costa. 2004. "To be or not to be in office again: an empirical test of a local political business cycle rationale." European Journal of Political Economy 20 (3):655-671.

Banks, Jeffrey S. and Rangarajan K. Sundaram. 1998. "Optimal Retention in Agency Problems." Journal of Economic Theory 82 (2):293-323.

Berger, Helge and Anika Holler. 2007. "What Determines Fiscal Policy?" Working Paper Series 2062, CESifo.

Berger, Helge and Ulrich Woitek. 1997. "Searching for Political Business Cycles in Germany." Public Choice 91 (2):179-197.

Bertrand, Marianne, Esther Duflo, and Sendhil Mullainathan. 2004. "How Much Should We Trust Differences-in-Differences Estimates?" The Quarterly Journal of Economics 119 (1):249-275.

Besley, Timothy J. 2006. Principled Agents? The Political Economy of Good Governance. imeus. Oxford University Press.

Blais, André and Richard Nadeau. 1992. "The Electoral Budget Cycle." Public Choice $74(4): 389-403$.

Brender, Adi and Allan Drazen. 2005. "Political budget cycles in new versus established democracies." Journal of Monetary Economics 52 (7):1271-1295.

Bucovetscy, Sam. 1991. "Asymmetric Tax Competition." Journal of Urban Economics $30(2): 167-181$.

Buettner, Thiess. 1999. "Nationaler und regionaler Steuerwettbewerb - Problematik und empirische Relevanz." Konjunkturpolitik 49:111-142.

2003. "Tax Base Effects and Fiscal Externalities of Local Capital Taxation: Evidence from a Panel of German Jurisdictions." Journal of Urban Economics 54 (1):110 - 128. 
Buti, Marco and Paul van den Noord. 2003. "Discretionary Fiscal Policy and Elections: The Experience of the Early Years of EMU." OECD Working Paper Series 351.

Cameron, A. Colin, Jonah B. Gelbach, and Douglas L. Miller. 2011. "Robust Inference with Multi-way Clustering." Journal of Business and Economic Statistics 29:238-249.

Dahlberg, Matz and Eva Mörk. 2011. "Is There an Election Cycle in Public Employment? Separating Time Effects from Election Year Effects." CESifo Economic Studies 57 (3):480498.

De Haan, J. and D. Zelhorst. 1993. "Positive Theories of Public Debt: Some Evidence for Germany." In The Political Economy of Government Debt, edited by H.A.A. Verbon and F.A.A.M. van Winden. Elsevier Science Publishers B. V., Amsterdam, 295-306.

Desai, M., F. Foley, and J. Hines. 2007. "Labor and Capital Shares of the Corporate Tax Burden: International Evidence." Mimeo.

Deutsche Bundesbank. 2000. "Die Entwicklung der Kommunalfinanzen seit Mitte der neunziger Jahre." Monatsbericht (Juni), Deutsche Bundesbank.

. 2007. "Zur Entwicklung der Gemeindefinanzen seit dem Jahr 2000." Monatsbericht (Juli), Deutsche Bundesbank.

Devereux, Michael P., Ben Lockwood, and Michela Redoano. 2008. "Do countries compete over corporate tax rates?" Journal of Public Economics 92 (5-6):1210 - 1235.

Drazen, Allan. 2000. Political Economy in Macroeconomics. Princeton University Press.

Drazen, Allan and Marcela Eslava. 2010. "Electoral manipulation via voter-friendly spending: Theory and evidence." Journal of Development Economics 92 (1):39 - 52.

Efthyvoulou, Georgios. 2012. "Political budget cycles in the European Union and the impact of political pressures." Public Choice forthcoming.

Ferejohn, John. 1986. "Incumbent Performance and Electoral Control." Public Choice 50 (1$3): 5-25$.

Ferraz, Claudio and Frederico Finan. 2011. "Electoral Accountability and Corruption: Evidence from the Audits of Local Governments." American Economic Review 101 (4):12741311.

Foremny, Dirk and Nadine Riedel. 2012. "Business Taxes and the Electoral Cycle." Working Paper Series 3729, CESifo. 
Fuess, Roland and Michael Bechtel. 2008. "Partisan Politics and Stock Market Performance: The Effect of Expected Government Partisanship on Stock Returns in the 2002 German Federal Election." Public Choice 135 (3-4):131-150.

Furdas, Marina and Krisztina Kis-Katos. 2010. "Does partisanship affect local fiscal policies? A regression discontinuity analysis for West German cities." mimeo, University of Freiburg.

Gagliarducci, Stefano and Tommaso Nannicini. 2012. "Do Better Paid Politicians Perform Better? Disentangling Incentives from Selection." Journal of the European Economic Association forthcoming.

Galli, Emma and Stefania P.S. Rossi. 2002. "Political Budget Cycles: The Case of the Western German Lï $\frac{1}{2}$ nder." Public Choice 110 (3):283-303.

Hallerberg, Mark, Rolf Strauch, and Juergen von Hagen. 2007. "The design of fiscal rules and forms of governance in European Union countries." European Journal of Political Economy 23 (2):338-359.

Kneebone, Ronald D. and Kenneth J. McKenzie. 2001. "Electoral and partisan cycles in fiscal policy: An examination of Canadian provinces." International Tax and Public Finance $8(5-6): 753-774$.

Lindbeck, Assar. 1976. "Stabilization Policy in Open Economies with Endogenous Politicians." American Economic Review 66 (2):1-19.

Mikesell, John L. 1978. "Election Periods and State Tax Policy Cycles." Public Choice $33(3): 99-106$.

Mink, Mark and Jakob de Haan. 2005. "Has the Stability and Growth Pact Impeded Political Budget Cycles in the European Union?" Working Paper Series 1532, CESifo.

Nelson, Michael A. 2000. "Electoral Cycles and the Politics of State Tax Policy." Public Finance Review 28 (6):540-560.

Nordhaus, William D. 1975. "The Political Business Cycle." Review of Economic Studies 42 (2):169-190.

Persson, Torsten and Guido Tabellini. 2001. Macroeconomic Policy, Credibility and Politics. Abingdon: Routledge.

- 2003a. "Do Electoral Cycles Differ Across Political Systems?" IGIER Working Paper No.232.

2003b. The economic effects of constitutions. Cambridge: MIT Press. 
Pettersson-Lidbom, Per. 2001. "An Empirical Investigation of the Strategic Use of Debt." Journal of Political Economy 109 (3):570-583.

2003. "A Test of the Rational Electoral-Cycle Hypothesis." University of Stockholm, mimeo .

Potrafke, Niklas. 2011. "Economic Freedom and Government Ideology Across the German States." Regional Studies fortcoming.

Rodden, Jonathan. 2001. "And the Last Shall Be the First: Federalism and Fiscal Outcomes in Germany." Working paper, Massachusetts Institute of Technology.

Rogoff, Kenneth. 1990. "Equilibrium Political Budget Cycles." American Economic Review $80(1): 21-36$.

Rogoff, Kenneth and Anne Sibert. 1988. "Elections and Macroeconomic Policy Cycles." Review of Economic Studies 55 (1):1-16.

Rosenberg, Jacob. 1992. "Rationality and the Political Business Cycle: The Case of Local Government." Public Choice 73 (1):71-81.

Schneider, Christina. 2010. "Fighting with one hand tied behind the back: political budget cycles in the West German states." Public Choice 142 (1):125-150.

Schuknecht, Ludger. 2000. "Fiscal Policy Cycles and Public Expenditure in Developing Countries." Public Choice 102 (1-2):115-130.

Seitz, Helmut. 2000. "Fiscal Policy, Deficits and Politics of Subnational Governments: The Case of the German Laender." Public Choice 102 (3-4):183-218.

Shi, Min and Jakob Svensson. 2006. "Political budget cycles: Do they differ across countries and why?" Journal of Public Economics 90 (8-9):1367-1389.

Tufte, Edward R. 1978. Political Control of the Economy. Princeton University Press.

Veiga, Linda and Francisco Veiga. 2007. "Political business cycles at the municipal level." Public Choice 131 (1):45-64.

von Hagen, Juergen. 2006. "Fiscal Rules and Fiscal Performance in the European Union and Japan." Monetary and Economic Studies 24 (1):25-60.

Wilson, John Douglas. 1999. "Theories of Tax Competition." National Tax Journal $52(2): 269-304$. 


\section{Graphs and tables}

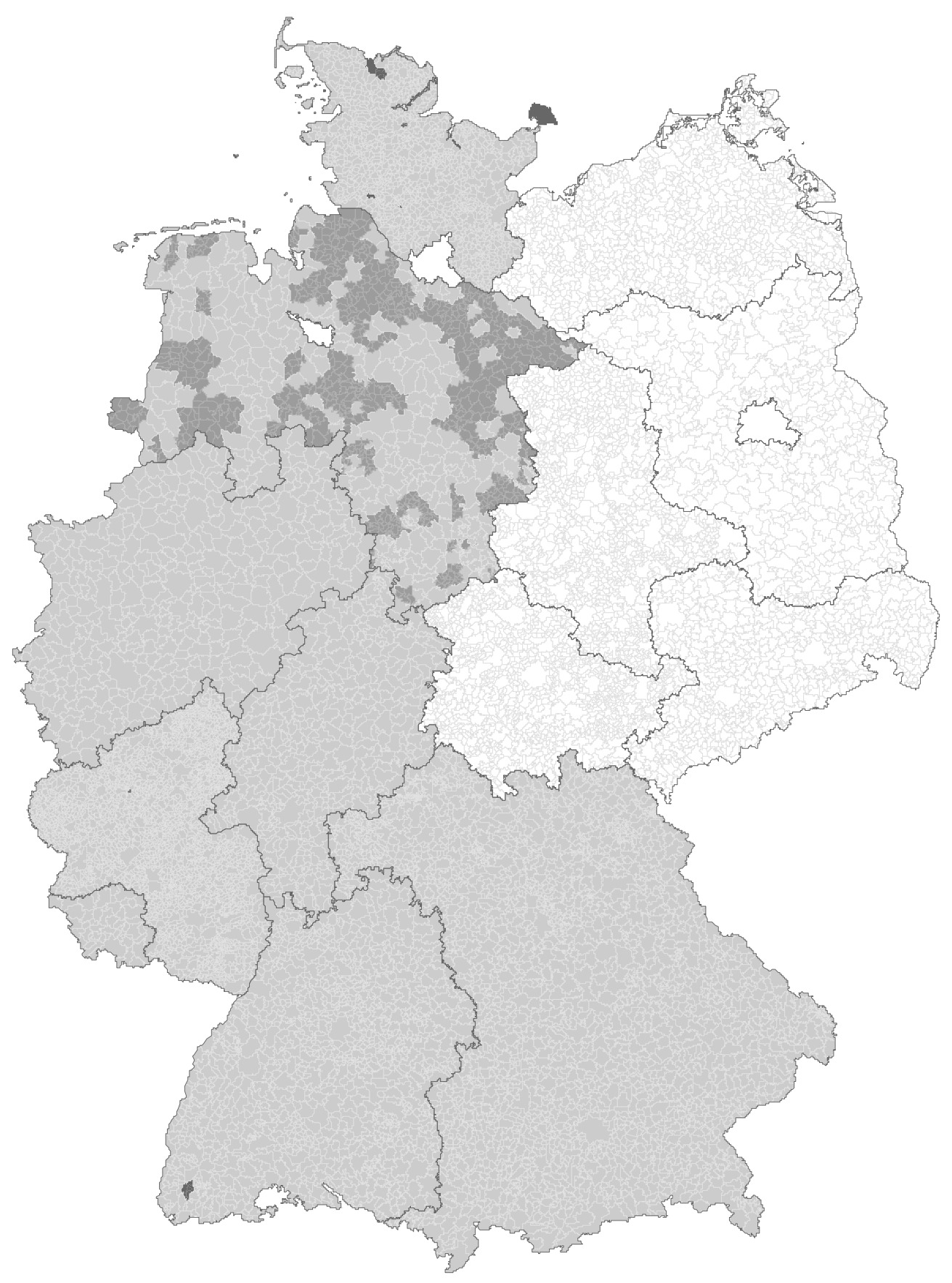

Notes: All municipalities shaded in light gray are included in our sample. All areas in Lower Saxony shaded in dark gray belong to joint municipalities and are dropped from the sample. Municipalities shaded in black were subject to mergers during our sample period and are also dropped from the sample.

Figure 1: Sample 

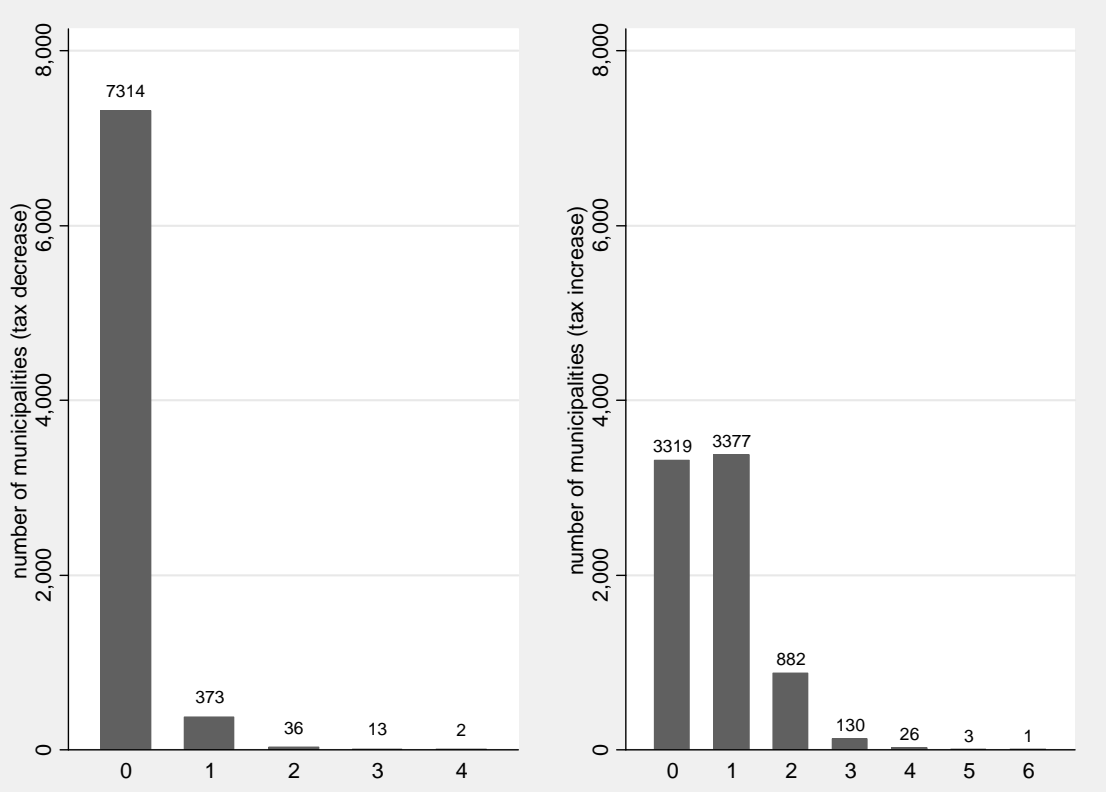

Notes: Left (right) panel depicts the number of municipalities which experience a particular number of tax decreases (increases) within our sample period. Note that no municipality decreased (increased) its tax rate more than four (six) times.

Figure 2: Tax changes

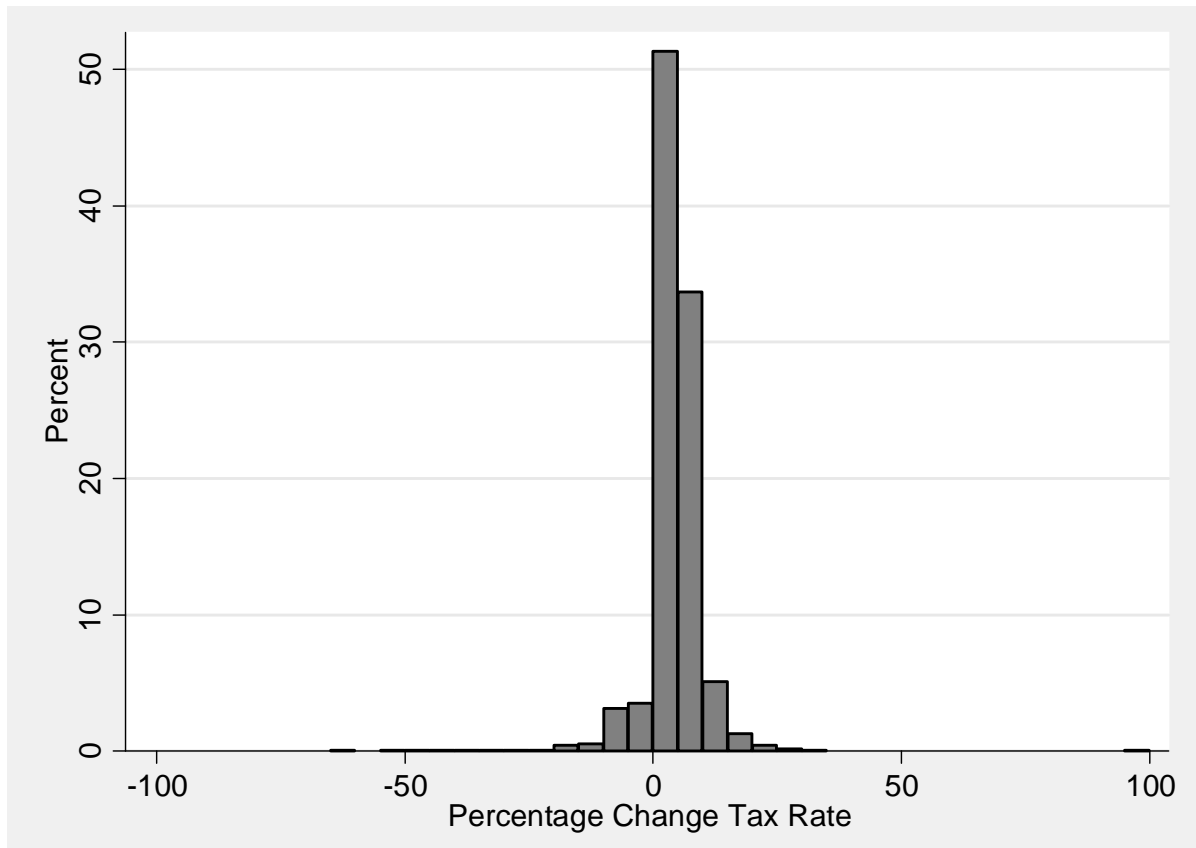

Notes: Variable distribution for the growth rate of the local business tax in our sample.

Figure 3: Tax rate growth 


\begin{tabular}{lccc}
\hline federal state & \multicolumn{3}{c}{ years } \\
\hline Schleswig-Holstein & 1998 & 2003 & 2008 \\
Lower Saxony (Niedersachsen) & 1996 & 2001 & 2006 \\
North Rhine-Westphalia (Nordrhein-Westfalen) & 1999 & 2004 & 2009 \\
Hesse (Hessen) & 1996 & 2001 & 2006 \\
Rhineland-Palatinate (Rheinland-Pfalz) & 1999 & 2004 & 2009 \\
Baden-Wuerttemberg & 1999 & 2004 & 2009 \\
Bavaria (Bayern) & 1996 & 2002 & 2008 \\
Saarland & 1999 & 2004 & 2009 \\
\hline
\end{tabular}

Notes: Election years for local council elections in our sample states.

Table 1: Elections at the local level 


\begin{tabular}{|c|c|c|c|c|}
\hline Variable & Mean & Std.Dev. & Min & Max \\
\hline \multicolumn{5}{|l|}{ Controls } \\
\hline credits & -.003 & .092 & -2.828 & 2.467 \\
\hline unemployment & .029 & .013 & 0.000 & .190 \\
\hline young & .163 & .033 & 0.000 & .600 \\
\hline old & .180 & .042 & 0.000 & .500 \\
\hline city & .183 & .387 & 0.000 & 1.000 \\
\hline debt & 2.368 & 1.034 & .481 & 6.831 \\
\hline population (standardized) & -0.02 & 1.000 & -.250 & 41.502 \\
\hline income (logs) & 9.763 & .102 & 9.490 & 10.307 \\
\hline expenditures & .998 & 6.215 & -57.803 & 1053.085 \\
\hline \multicolumn{5}{|c|}{ Party controls - seat shares } \\
\hline $\mathrm{cdu}$ & .246 & .234 & 0.000 & 1.000 \\
\hline spd & .163 & .180 & 0.000 & 1.000 \\
\hline gruene & .014 & .035 & 0.000 & .375 \\
\hline fdp & .011 & .033 & 0.000 & .583 \\
\hline \multicolumn{5}{|l|}{ Tax data } \\
\hline collection rate & 335.658 & 31.898 & 0 & 900 \\
\hline diff. collection rate & 1.300 & 6.571 & -150 & 200 \\
\hline \multicolumn{5}{|l|}{ Dependent variables } \\
\hline$\underline{\tau}^{\text {binary }}$ & .007 & .084 & 0.000 & 1.000 \\
\hline$\overline{\bar{\tau}}^{\text {binary }}$ & .081 & .273 & 0.000 & 1.000 \\
\hline$\tau^{\text {growth }}$ & .369 & 1.974 & -61.224 & 100 \\
\hline \multicolumn{5}{|c|}{ Changes (Dep.var excluding zeros) } \\
\hline$\tau^{\text {growth }}$ if $\neq 0$ & 4.177 & 5.312 & -61.225 & 100 \\
\hline \multicolumn{5}{|c|}{$\mathrm{N}=69642, \mathrm{~T}=9(2000-2008), \mathrm{n}=7738$} \\
\hline
\end{tabular}

Notes: Definition of variables: credits: new credits minus repayments as share of annual revenues (missing public finance data for the federal state of Schleswig-Holstein for the years 2000 to 2002 required linear imputation), unemployment: unemployed people as share of total population (data is censored if less than three people are unemployed; the ratio is set to zero in that case), population: number of inhabitants (standardized), young: share of inhabitants aged 15 or younger, old: share of inhabitants aged 65 or older (population data for the year 2000 is missing and imputed through the group mean) city: dummy variable, debt: total municipal debt per capita (county level), income: income in Euro per capita (county level), expenditures: per capita expenditures on exogenous payments; party controls are the respective seat shares in the local council; collection rate: statutory business tax collection rate (including information for the year 1999 for the summary statistics).

Table 2: Summary statistics 


\begin{tabular}{|c|c|c|c|c|}
\hline \multirow{2}{*}{$\begin{array}{l}\text { Dependent Variable } \\
\tau^{\text {growth }}\end{array}$} & \multicolumn{4}{|c|}{ Individual Fixed Effect Model } \\
\hline & (a) & (b) & (c) & (d) \\
\hline$t_{t-1}$ & \multicolumn{4}{|c|}{-0.074} \\
\hline s.e. & $(0.022)$ & $(0.023)$ & $(0.100)$ & $(0.100)$ \\
\hline $\mathrm{p}$-value & 0.001 & 0.001 & 0.464 & 0.460 \\
\hline $95 \% \mathrm{CI}$ & {$[-0.117--0.030]$} & {$[-0.118--0.029]$} & {$[-0.273-0.126]$} & {$[-0.269-0.122]$} \\
\hline$t_{t}$ & \multicolumn{4}{|c|}{-0.170} \\
\hline s.e. & $(0.025)$ & $(0.027)$ & $(0.077)$ & $(0.077)$ \\
\hline p-value & 0.000 & 0.000 & 0.031 & 0.028 \\
\hline $95 \% \mathrm{CI}$ & {$[-0.219--0.121]$} & {$[-0.222--0.118]$} & {$[-0.324--0.016]$} & {$[-0.321--0.018]$} \\
\hline$t_{t+1}$ & \multicolumn{4}{|c|}{0.206} \\
\hline s.e. & $(0.024)$ & $(0.026)$ & $(0.098)$ & $(0.097)$ \\
\hline p-value & 0.000 & 0.000 & 0.039 & 0.034 \\
\hline $95 \% \mathrm{CI}$ & {$[0.159-0.253]$} & {$[0.155-0.257]$} & {$[0.011-0.401]$} & {$[0.015-0.397]$} \\
\hline Time FE & yes & yes & yes & yes \\
\hline Clustering & no & community & state-year & two-way \\
\hline
\end{tabular}

Notes: Dependent variable: annual percentage change in the statutory business tax rate. Coefficients for the pre-election, election, and post-election year are reported. Coefficients on other controls are presented in Table 10 in the appendix A. To assure that the matrix of orthogonality conditions is of full rank, exogenous regressors are partialed out in model (d). All models include individual fixed effects at the municipal level. Standard errors are clustered at the reported level. p-values in bold indicate that coefficients are significant at the $5 \%$ level.

Table 3: Baseline results

\begin{tabular}{lccccc}
\hline \multirow{2}{*}{ Dependent Variable } & $\bar{\tau}^{\text {growth }}$ & $\underline{\tau}^{\text {growth }}$ & & $\bar{\tau}^{\text {binary }}$ & $\underline{\tau}^{\text {binary }}$ \\
\cline { 2 - 3 } & $(\mathrm{a})$ & $(\mathrm{b})$ & & $(\mathrm{c})$ & $(\mathrm{d})$ \\
\hline$t_{t-1}$ & -0.082 & 0.008 & & -0.006 & $-0.003^{*}$ \\
\multirow{2}{*}{$t_{t}$} & $(0.098)$ & $(0.017)$ & & $(0.017)$ & $(0.002)$ \\
& $-0.157^{* *}$ & -0.013 & $-0.030^{* *}$ & -0.002 \\
$t_{t+1}$ & $(0.075)$ & $(0.012)$ & & $(0.012)$ & $(0.002)$ \\
& $0.218^{* *}$ & -0.012 & & $0.046^{* *}$ & 0.001 \\
& $(0.096)$ & $(0.012)$ & $(0.021)$ & $(0.002)$ \\
\hline
\end{tabular}

Notes: Dependent variable: positive (negative) annual percentage change in the statutory tax rate in models (a) and (b); binary variables indicating tax hikes and tax cuts in models (c) and (d). Individual (municipal) fixed effects included in models (a) and (b); state fixed effects in models (c) and (d). Time fixed effects included in all models. Standard errors are clustered at the state-year level. ${ }^{* * *} \mathrm{p}<0.01,{ }^{* *} \mathrm{p}<0.05,{ }^{*} \mathrm{p}<0.1$. Coefficients on other controls are depicted in Table 11 in the appendix. Columns (c) and (d) present the marginal effects of the binary specification for tax hikes and tax cuts respectively. Underlying regressions are presented in Table 11.

Table 4: Additional results 


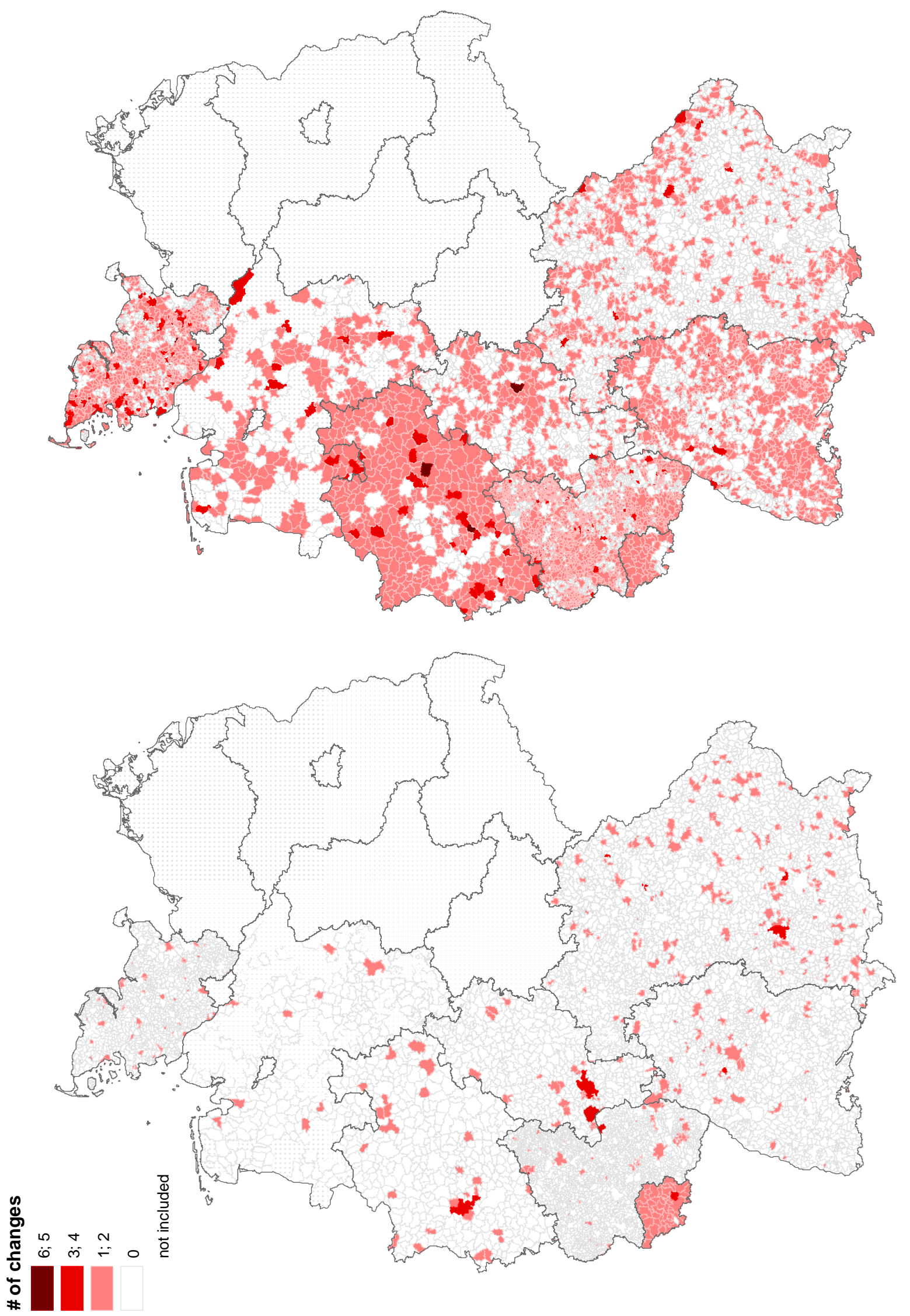

Figure 4: Number of changes (decreases/increases)

Notes: Left (right) panel graphically illustrates the number of tax cuts (hikes) experienced by our sample communities. Blank areas are not included in the data. 


\begin{tabular}{|c|c|c|c|c|}
\hline \multirow[t]{2}{*}{ Dependent Variable } & \multicolumn{4}{|c|}{$\tau^{\text {growth }}$} \\
\hline & (a) & (b) & (c) & (d) \\
\hline$t_{t-1}$ & $\begin{array}{l}-0.069 \\
(0.100)\end{array}$ & $\begin{array}{l}-0.069 \\
(0.100)\end{array}$ & $\begin{array}{l}-0.082 \\
(0.108)\end{array}$ & $\begin{array}{l}-0.078 \\
(0.110)\end{array}$ \\
\hline$t_{t}$ & $\begin{array}{c}-0.161^{* *} \\
(0.078)\end{array}$ & $\begin{array}{c}-0.161^{* *} \\
(0.078)\end{array}$ & $\begin{array}{l}-0.164^{*} \\
(0.088)\end{array}$ & $\begin{array}{r}-0.178^{* *} \\
(0.089)\end{array}$ \\
\hline$t_{t+1}$ & $\begin{array}{c}0.217^{*} \\
(0.110)\end{array}$ & $\begin{array}{l}0.214^{*} \\
(0.109)\end{array}$ & $\begin{array}{l}0.215^{*} \\
(0.110)\end{array}$ & $\begin{array}{l}0.211^{*} \\
(0.109)\end{array}$ \\
\hline$t_{t-1} \cdot I_{i, t}$ & & & & $\begin{array}{c}0.279 \\
(0.273)\end{array}$ \\
\hline$t_{t} \cdot I_{i, t}$ & & & & $\begin{array}{c}0.095 \\
(0.297)\end{array}$ \\
\hline$t_{t+1} \cdot I_{i, t}$ & & $\begin{array}{c}0.240 \\
(0.262)\end{array}$ & & $\begin{array}{c}0.173 \\
(0.279)\end{array}$ \\
\hline$t_{t-1} \cdot$ change - ideology & & & $\begin{array}{c}0.070 \\
(0.098)\end{array}$ & \\
\hline$t_{t} \cdot$ change - ideology & & & $\begin{array}{c}0.011 \\
(0.101)\end{array}$ & \\
\hline$t_{t+1} \cdot$ change $-i d e o l o g y$ & $\begin{array}{c}0.089 \\
(0.124)\end{array}$ & & $\begin{array}{c}0.100 \\
(0.126)\end{array}$ & \\
\hline
\end{tabular}

Notes: Dependent variable: annual percentage change in the statutory business tax rate. Municipality and time fixed effects included in all models. Standard errors are clustered at the state-year level. ${ }^{* * *} \mathrm{p}<0.01$, ${ }^{* *} \mathrm{p}<0.05,^{*} \mathrm{p}<0.1$. Models (a) and (c) augment the set of regressors by an interaction between the electoral cycle and a dummy variable indicating changes in the ideological composition of the local council, models (b) and (d) with an index for the general composition of the local council ( $I_{i t}$, see definition in the text). For results of control variables refer to Table 12 in the appendix.

Table 5: Changes in the composition of councils

\begin{tabular}{lcccc}
\hline Dependent Variable & $\tau^{\text {growth }}$ & & $\bar{\tau}^{\text {binary }}$ & $\underline{\tau}^{\text {binary }}$ \\
\cline { 2 - 2 } & $(\mathrm{a})$ & & $(\mathrm{b})$ & $(\mathrm{c})$ \\
\hline$t_{t-1}$ & -0.032 & & -0.071 & $-0.567^{*}$ \\
& $(0.079)$ & & $(0.248)$ & $(0.298)$ \\
$t_{t-1}$ & $-0.150^{* *}$ & $-0.514^{* *}$ & -0.236 \\
\multirow{2}{*}{$t_{t}$} & $(0.067)$ & $(0.217)$ & $(0.226)$ \\
& 0.124 & & $0.543^{* *}$ & 0.097 \\
& $(0.090)$ & $(0.224)$ & $(0.258)$ \\
$\operatorname{tax}_{t-1}$ & $-0.102^{* * *}$ & $-0.028^{* * *}$ & $0.013^{* * *}$ \\
& $(0.010)$ & $(0.004)$ & $(0.002)$ \\
\hline
\end{tabular}

Notes: Dependent variable: annual percentage change in the statutory business tax rate in model (a) and binary variables indicating tax hikes and tax cuts in models (b) and (c). Model (a) includes municipality fixed effects, (b) and (c) state level fixed effects. Time fixed effects always included. Standard errors are clustered at the state-year level, ${ }^{* * *} \mathrm{p}<0.01,{ }^{* *} \mathrm{p}<0.05,{ }^{*} \mathrm{p}<0.1$.

Table 6: Inclusion of the lagged tax level 


\begin{tabular}{|c|c|c|}
\hline \multirow[t]{2}{*}{ Dependent Variable } & $\tau^{e f f e c t i v e}$ & $\tau^{\text {difference }}$ \\
\hline & (a) & (b) \\
\hline$t_{t-1}$ & $\begin{array}{l}-0.074 \\
(0.090)\end{array}$ & $\begin{array}{c}-0.212 \\
(0.359)\end{array}$ \\
\hline$t_{t}$ & $\begin{array}{c}-0.153^{* *} \\
(0.070)\end{array}$ & $\begin{array}{c}-0.532^{*} \\
(0.269)\end{array}$ \\
\hline$t_{t+1}$ & $\begin{array}{c}0.193^{* *} \\
(0.088)\end{array}$ & $\begin{array}{c}0.714^{* *} \\
(0.352)\end{array}$ \\
\hline
\end{tabular}

Notes: Dependent variable: annual percentage change in the effective business tax rate in model (a) and first difference in the local business tax rate in model (b). Time and municipality fixed effects included in all models. Standard errors are clustered at the state-year level. Dependent variable in (a) is the effective tax rate, in (b) the first difference. For results of control variables refer to Table 13 in the appendix.

Table 7: Other definitions of the dependent variable

\begin{tabular}{lccccc}
\hline Dependent Variable & \multicolumn{5}{c}{$\tau^{\text {growth }}$} \\
\cline { 2 - 6 } & $(\mathrm{a})$ & $(\mathrm{b})$ & $(\mathrm{c})$ & $(\mathrm{d})$ & $(\mathrm{e})$ \\
\hline$t_{t-2}$ & 0.047 & & & & \\
& $(0.082)$ & & & & \\
$t_{t-1}$ & & -0.073 & & & \\
$t_{t}$ & & $(0.091)$ & & & \\
& & & $-0.170^{* *}$ & & \\
$t_{t+1}$ & & & $(0.075)$ & & $0.247^{* * *}$ \\
& & & & $(0.090)$ & \\
$t_{t+2}$ & & & & & 0.007 \\
& & & & & \\
\hline
\end{tabular}

Notes: Dependent variable: annual percentage change in the statutory business tax rate. Time and municipality fixed effects included in all models. Standard errors are clustered at the state-year level.

Table 8: Separate inclusion of electoral year dummies 


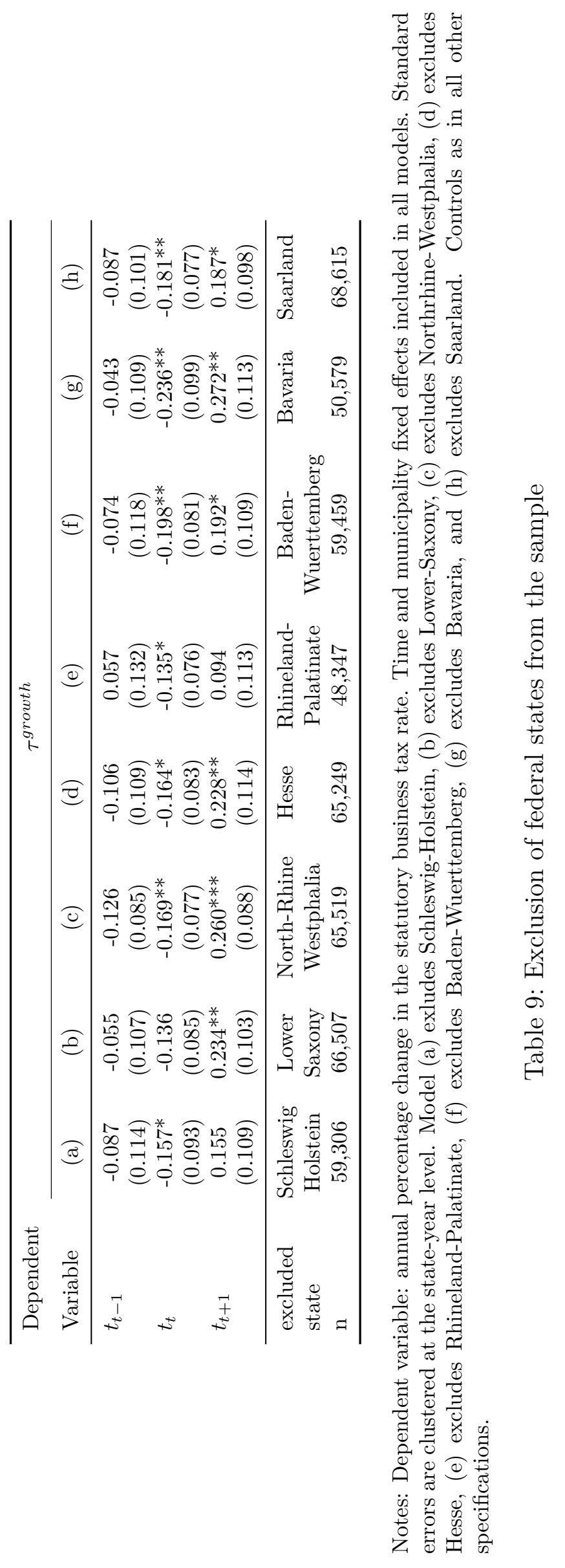




\section{A. Detailed Tables}

\begin{tabular}{lccc}
\hline Dependent Variable & \multicolumn{3}{c}{$\tau^{\text {growth }}$} \\
\cline { 2 - 4 } & $(\mathrm{a})$ & $(\mathrm{b})$ & $(\mathrm{c})$ \\
\hline credits & $0.265^{* * *}$ & $0.265^{* *}$ & $0.265^{* *}$ \\
& $(0.093)$ & $(0.123)$ & $(0.109)$ \\
income p.c. & 0.666 & 0.666 & 0.666 \\
& $(0.561)$ & $(0.533)$ & $(1.423)$ \\
debt p.c. & -0.033 & -0.033 & -0.033 \\
& $(0.042)$ & $(0.035)$ & $(0.089)$ \\
expenditures & $-0.019^{*}$ & -0.019 & -0.019 \\
& $(0.011)$ & $(0.020)$ & $(0.031)$ \\
unemployment & $-2.285^{*}$ & -2.285 & -2.285 \\
& $(1.387)$ & $(1.434)$ & $(2.004)$ \\
population & 0.238 & 0.238 & 0.238 \\
& $(0.429)$ & $(0.164)$ & $(0.268)$ \\
young & 0.519 & 0.519 & 0.519 \\
old & $(0.668)$ & $(1.278)$ & $(1.144)$ \\
& -0.801 & -0.801 & -0.801 \\
spd & $(0.673)$ & $(1.178)$ & $(1.029)$ \\
& $0.363^{* *}$ & $0.363^{* *}$ & 0.363 \\
cdu & $(0.184)$ & $(0.175)$ & $(0.273)$ \\
fdp & $0.302^{* *}$ & $0.302^{* *}$ & 0.302 \\
& $(0.152)$ & $(0.143)$ & $(0.327)$ \\
gruene & $-2.033^{* *}$ & $-2.033^{* * *}$ & -2.033 \\
Constant & $(0.789)$ & $(0.678)$ & $(1.539)$ \\
& 0.373 & 0.373 & 0.373 \\
Observations & $(0.708)$ & $(0.925)$ & $(1.153)$ \\
Groups & -6.183 & -6.183 & -6.183 \\
& $(5.425)$ & $(5.150)$ & $(13.754)$ \\
\hline & 69,083 & 69,083 & 69,083 \\
& 0.011 & 0.011 & 0.011 \\
& 7,714 & 7,714 & 7,714 \\
\hline & & & \\
& & & \\
& & &
\end{tabular}

Notes: Results of control variables for the estimations presented in Table 3 in the text. ${ }^{* * *} \mathrm{p}<0.01,{ }^{* *}$ $\mathrm{p}<0.05,{ }^{*} \mathrm{p}<0.1$

Table 10: Regression results control variables 


\begin{tabular}{|c|c|c|c|c|}
\hline \multirow[t]{2}{*}{ Dependent Variable } & $\bar{\tau}^{\text {growth }}$ & $\underline{\tau}^{\text {growth }}$ & $\bar{\tau}^{\text {binary }}$ & $\underline{\tau}^{\text {binary }}$ \\
\hline & (a) & (b) & (c) & (d) \\
\hline$t_{t-1}$ & -0.082 & 0.008 & -0.087 & $-0.551^{*}$ \\
\hline$t_{t-1}$ & $\begin{array}{c}-0.157^{* *} \\
(0.075)\end{array}$ & $\begin{array}{l}-0.013 \\
(0.012)\end{array}$ & $\begin{array}{c}-0.521^{* *} \\
(0.220)\end{array}$ & $\begin{array}{l}-0.220 \\
(0.228)\end{array}$ \\
\hline$t_{t+1}$ & $\begin{array}{c}0.218^{* *} \\
(0.096)\end{array}$ & $\begin{array}{l}-0.012 \\
(0.012)\end{array}$ & $\begin{array}{c}0.532^{* *} \\
(0.228)\end{array}$ & $\begin{array}{c}0.094 \\
(0.251)\end{array}$ \\
\hline credits & $\begin{array}{c}0.310^{* * *} \\
(0.084)\end{array}$ & $\begin{array}{l}-0.045 \\
(0.069)\end{array}$ & $\begin{array}{c}0.532^{* * *} \\
(0.156)\end{array}$ & $\begin{array}{l}-0.403 \\
(0.565)\end{array}$ \\
\hline income p.c. & $\begin{array}{c}1.265 \\
(1.378)\end{array}$ & $\begin{array}{l}-0.599 \\
(0.364)\end{array}$ & $\begin{array}{l}-0.450 \\
(0.516)\end{array}$ & $\begin{array}{c}1.678^{* * *} \\
(0.501)\end{array}$ \\
\hline debt p.c. & $\begin{array}{l}-0.033 \\
(0.081)\end{array}$ & $\begin{array}{l}-0.001 \\
(0.020)\end{array}$ & $\begin{array}{c}0.040 \\
(0.089)\end{array}$ & $\begin{array}{l}-0.015 \\
(0.087)\end{array}$ \\
\hline expenditures & $\begin{array}{c}0.015 \\
(0.013)\end{array}$ & $\begin{array}{l}-0.034 \\
(0.032)\end{array}$ & $\begin{array}{c}0.007 \\
(0.010)\end{array}$ & $\begin{array}{c}0.033^{* * *} \\
(0.013)\end{array}$ \\
\hline unemployment & $\begin{array}{l}-2.442 \\
(1.916)\end{array}$ & $\begin{array}{c}0.157 \\
(0.481)\end{array}$ & $\begin{array}{l}-0.210 \\
(3.682)\end{array}$ & $\begin{array}{l}-1.472 \\
(5.524)\end{array}$ \\
\hline population & $\begin{array}{c}0.459^{* *} \\
(0.213)\end{array}$ & $\begin{array}{l}-0.221 \\
(0.150)\end{array}$ & $\begin{array}{c}-0.266^{* * *} \\
(0.071)\end{array}$ & $\begin{array}{c}0.074^{* * *} \\
(0.014)\end{array}$ \\
\hline young & $\begin{array}{c}0.076 \\
(0.719)\end{array}$ & $\begin{array}{c}0.443 \\
(1.053)\end{array}$ & $\begin{array}{c}0.708 \\
(0.525)\end{array}$ & $\begin{array}{l}-1.101 \\
(1.930)\end{array}$ \\
\hline old & $\begin{array}{c}0.475 \\
(0.626)\end{array}$ & $\begin{array}{l}-1.276 \\
(0.938)\end{array}$ & $\begin{array}{c}1.120^{* * *} \\
(0.399)\end{array}$ & $\begin{array}{l}-0.582 \\
(1.548)\end{array}$ \\
\hline city & & & $\begin{array}{c}0.062 \\
(0.061)\end{array}$ & $\begin{array}{c}0.072 \\
(0.138)\end{array}$ \\
\hline spd & $\begin{array}{c}0.346 \\
(0.258)\end{array}$ & $\begin{array}{c}0.017 \\
(0.067)\end{array}$ & $\begin{array}{c}0.129 \\
(0.159)\end{array}$ & $\begin{array}{c}0.344 \\
(0.335)\end{array}$ \\
\hline cdu & $\begin{array}{c}0.289 \\
(0.322)\end{array}$ & $\begin{array}{c}0.013 \\
(0.060)\end{array}$ & $\begin{array}{c}0.165 \\
(0.103)\end{array}$ & $\begin{array}{c}0.064 \\
(0.266)\end{array}$ \\
\hline $\mathrm{fdp}$ & $\begin{array}{l}-2.514^{*} \\
(1.482)\end{array}$ & $\begin{array}{c}0.481 \\
(0.461)\end{array}$ & $\begin{array}{l}-0.497 \\
(0.583)\end{array}$ & $\begin{array}{c}3.179 * * * \\
(0.907)\end{array}$ \\
\hline gruene & $\begin{array}{c}0.552 \\
(1.035)\end{array}$ & $\begin{array}{l}-0.178 \\
(0.342)\end{array}$ & $\begin{array}{l}-0.990 \\
(0.650)\end{array}$ & $\begin{array}{c}3.447^{* * *} \\
(1.014)\end{array}$ \\
\hline Constant & $\begin{array}{c}-12.169 \\
(13.293)\end{array}$ & $\begin{array}{l}5.986^{*} \\
(3.562)\end{array}$ & $\begin{array}{c}1.664 \\
(4.924)\end{array}$ & $\begin{array}{c}-21.149 * * * \\
(4.908)\end{array}$ \\
\hline
\end{tabular}

Notes: Results of control variables for the estimations presented in Table 4 in the text. ${ }^{* * *} \mathrm{p}<0.01,{ }^{* *}$ $\mathrm{p}<0.05,{ }^{*} \mathrm{p}<0.1$

Table 11: Regression results control variables 


\begin{tabular}{lcccc}
\hline \multirow{2}{*}{ Dependent Variable } & \multicolumn{4}{c}{$\tau^{\text {growth }}$} \\
\cline { 2 - 5 } & $(\mathrm{a})$ & $(\mathrm{b})$ & $(\mathrm{c})$ & $(\mathrm{d})$ \\
\hline \multirow{2}{*}{ credits } & $0.261^{* *}$ & $0.261^{* *}$ & $0.262^{* *}$ & $0.261^{* *}$ \\
income p.c. & $(0.109)$ & $(0.109)$ & $(0.109)$ & $(0.109)$ \\
& 0.761 & 0.756 & 0.755 & 0.748 \\
debt p.c. & $(1.469)$ & $(1.472)$ & $(1.468)$ & $(1.476)$ \\
& -0.013 & -0.013 & -0.012 & -0.013 \\
expenditures & $(0.100)$ & $(0.100)$ & $(0.100)$ & $(0.100)$ \\
& -0.019 & -0.019 & -0.019 & -0.019 \\
unemployment & $(0.032)$ & $(0.032)$ & $(0.032)$ & $(0.032)$ \\
& -2.093 & -2.079 & -2.079 & -2.078 \\
population & $(2.002)$ & $(1.976)$ & $(1.998)$ & $(1.974)$ \\
& 0.171 & 0.167 & 0.176 & 0.164 \\
young & $(0.249)$ & $(0.249)$ & $(0.249)$ & $(0.248)$ \\
old & 0.504 & 0.505 & 0.510 & 0.517 \\
& $(1.145)$ & $(1.146)$ & $(1.144)$ & $(1.147)$ \\
spd & -0.811 & -0.813 & -0.809 & -0.800 \\
& $(1.027)$ & $(1.026)$ & $(1.026)$ & $(1.025)$ \\
cdu & 0.402 & 0.418 & 0.388 & 0.439 \\
& $(0.282)$ & $(0.283)$ & $(0.279)$ & $(0.282)$ \\
fdp & 0.337 & 0.345 & 0.340 & 0.353 \\
gruene & $(0.333)$ & $(0.335)$ & $(0.332)$ & $(0.339)$ \\
Constant & -1.941 & -1.938 & -1.950 & -1.947 \\
& $(1.567)$ & $(1.568)$ & $(1.569)$ & $(1.561)$ \\
& 0.219 & 0.217 & 0.208 & 0.199 \\
& $(1.186)$ & $(1.184)$ & $(1.184)$ & $(1.180)$ \\
& -7.060 & -7.017 & -7.002 & -6.949 \\
& $(14.196)$ & $(14.225)$ & $(14.179)$ & $(14.251)$ \\
\hline
\end{tabular}

Notes: Results of control variables for the estimations presented in Table 5 in the text. ${ }^{* * *} \mathrm{p}<0.01,{ }^{* *}$ $\mathrm{p}<0.05,{ }^{*} \mathrm{p}<0.1$

Table 12: Regression results control variables 


\begin{tabular}{|c|c|c|}
\hline \multirow[t]{2}{*}{ Dependent Variable } & \multirow{2}{*}{$\frac{\tau^{\text {effective }}}{\text { (a) }}$} & \multirow{2}{*}{$\frac{\tau^{\text {difference }}}{(\mathrm{b})}$} \\
\hline & & \\
\hline \multirow[t]{2}{*}{ credits } & $0.272^{* * *}$ & $0.993^{* * *}$ \\
\hline & $(0.097)$ & $(0.360)$ \\
\hline \multirow[t]{2}{*}{ income p.c. } & 0.660 & 2.467 \\
\hline & $(1.299)$ & $(4.912)$ \\
\hline \multirow[t]{2}{*}{ debt p.c. } & -0.027 & -0.104 \\
\hline & $(0.079)$ & $(0.310)$ \\
\hline \multirow{2}{*}{ expenditures } & -0.002 & -0.030 \\
\hline & $(0.020)$ & $(0.084)$ \\
\hline \multirow[t]{2}{*}{ unemployment } & -2.132 & -8.196 \\
\hline & $(1.799)$ & $(6.945)$ \\
\hline \multirow[t]{2}{*}{ population } & 0.237 & 1.005 \\
\hline & $(0.229)$ & $(1.042)$ \\
\hline \multirow[t]{2}{*}{ young } & 0.274 & 2.276 \\
\hline & $(0.847)$ & $(3.963)$ \\
\hline \multirow[t]{2}{*}{ old } & -0.434 & -1.851 \\
\hline & $(0.764)$ & $(3.469)$ \\
\hline \multirow[t]{2}{*}{ spd } & 0.346 & 1.302 \\
\hline & $(0.249)$ & $(0.981)$ \\
\hline \multirow[t]{2}{*}{$\mathrm{cdu}$} & 0.269 & 1.283 \\
\hline & $(0.297)$ & $(1.257)$ \\
\hline \multirow[t]{2}{*}{ fdp } & -1.956 & -7.679 \\
\hline & $(1.354)$ & $(5.863)$ \\
\hline \multirow[t]{2}{*}{ gruene } & 0.645 & 0.558 \\
\hline & $(1.125)$ & $(4.097)$ \\
\hline \multirow[t]{2}{*}{ Constant } & -6.135 & -23.123 \\
\hline & $(12.540)$ & $(47.398)$ \\
\hline
\end{tabular}

Notes: Results for controls of the estimations presented in Table 7 in the text. ${ }^{* * *} \mathrm{p}<0.01,{ }^{* *} \mathrm{p}<0.05,{ }^{*}$ $\mathrm{p}<0.1$

Table 13: Regression results control variables 